\title{
ARTIKEL ALDA MEGAWATI.pdf by
}

Submission date: 24-Jun-2021 09:06AM (UTC+0700)

Submission ID: 1611351710

File name: ARTIKEL ALDA MEGAWATI.pdf (324.06K)

Word count: 2397

Character count: 16357 


\title{
Relation Between Leukocyte Count and CRP (C-Reactive Protein) Levels in Typhoid Fever Patients [Hubungan Jumlah Leukosit dan Kadar CRP (C-Reactive Protein) Pada Pasien Demam Tifoid]
}

\author{
Alda Megawati ${ }^{1)}$, Andika Aliviameita ${ }^{8,2)}$ \\ ${ }^{1,2)}$ Program Studi Teknologi Laboratorium Medis, Fakultas Ilmu kesehatan Universitas Muhammadiyah \\ Sidoarjo, Indonesia \\ *Email Penulis Korespondensi: aldamegawati23@gmail.com
}

\begin{abstract}
Typhoid fever is a systemic infectious disease characterized by the patient experiencing fever and abdominal pain due to the spread of Salmonella bacteria. Typhoid fever sufferers cause the immune system to decline which can affect changes in the number of white blood cells and in an infection, an inflammatory process occurs that produces cytokines which are the core stimulators of acute phase protein production, including $C$ reactive protein $(C$-reactive protein $=C R P)$. This study was conducted in April 2021 with the aim of knowing the relationship between the number of leukocytes and CRP levels in typhoid fever patients at RA Basoeni Mojokerto Hospital. The design carried out in this study was a laboratory experimental, the sample needed in this study was 30 typhoid fever patients at RA Basoeni Hospital. Examination of the leukocyte count uses an automatic method with a Hematology analyzer, while CRP examination uses a semi-quantitative method. In the Spearman correlation test, it was found that there was no significant relationship between the number of leukocytes and the level of CRP $p=$ 0.460 .
\end{abstract}

Keywords - typhoid fever, leukocyte, CRP $(C$-reactive protein $=C R P)$

Abstrak. Demam tifoid adalah penyakit infeksi yang bersifat sistemik dengan ciri penderita mengalami demam dan nyeri abdominal karena penyebaran dari bakteri Salmonella. Penderita demam tilid menyebabkan sistem kekebalan menurun yang dapat mempengaruhi perubahan jumlah sel darah putih dan pada suatu infeksi, terjadi proses inflamasi yang menghasilkan sitokin yang merupakan stimulator inti dari produksi protein fase akut, termasuk protein $C$-reaktif (C-reactive protein=CRP). Penelitian ini dilakukan pada April 2021 dengan bertujuan untuk mengetahui hubungan jumlah leukosit dan kadar CRP pada pasien demam tifoid di RSUD RA Basoeni Mojokerto. Desain yang dilakukan pada penelitian ini eksperimental laboratorik, sampel yang dibutuhkan pada penelitian ini adalah 30 pasien demam tifoid di RSUD RA Basoeni. Pemeriksaan jumlah leukosit menggunakan metode automatis dengan alat Hematology analyzer, pd6 pemeriksaan CRP menggunakan metode semi kuantitatif. Pada uji korelasi Spearman diperoleh hasil tidak ada hubungan yang signifikan antara jumlah leukosit dan kadar $C R P p=0,460$.

Kata Kunci - Demam Tifoid, Leukosit, CRP (C-Reactive Protein)

\section{Pendahuluan}

Demam tifoid adalah penyakit infeksi yang bersifat sistemik dengan ciri penderita mengalami demam dan nyeri abdominal karena penyebaran dari bakteri Salmonella [1]. Menurut data Dinas Kesehatan Provinsi Jawa Tin 4t tahun 2013, penyakit demam tifoid merupakan 10 penyakit terbanyak di Provinsi Jawa Timur [2].

Leukosit adalah sel darah yang mengandung inti sel, disebu 4 uga sel darah putih. Sistem kekebalan yang menurun dapat mempengaruhi perubahan jumlah sel darah putih, salah satunya pada penderita demam tifoid [3] Sistem imun tubuh yang turun dapat menyebabkan terganggunya mekanisme respon imun seluler dan humoral, 4 hingga untuk mengembalikan keseimbangan sistem imun dapat dilakukan dengan pemberian imunostimulator [4]. Pemeriksaan laboratorium pada pasien demam tifoid akan menunjukan adanya leukopenia, leukositosis atau leukosit nor 2al [5]

C-reactive protein merupakan salah satu protein fase akut non spesifik yang dihasilkan oleh hati dal 2 kadar dalam darah meningkat pada inflamasi sebagai akibat respon imun non spesifik [6]. Bakteri umumnya menyebabkan penyakit yang lebih berat akibat inflamasi yang lebih luas sehir 1 ga lebih banyak melepaskan sitokin interleukin (IL) 6 yang merupakan sitokin penginduksi sintesis CRP [7]. Pada suatu infeksi, terjadi proses inflamasi yang menghasilkan sitokin yang merupakan stimulator inti dari produksi protein fase akut termasuk protein C-reaktif (Creactive protein $=\mathrm{CRP})[6]$. 


\section{METODE}

\section{A. Desain penelitian}

Penelitian ini menggunakan analisis kuantitatif metode eksperimental laboratorik untuk mengetahui hubu ngan jumlah leukosit dan kadar CRP pada penderita demam tifoid. Dengan menggunakan desain penelitian ini yaitu potong lintang atau Cross sectional.

\section{B. Populasi dan sampel}

Populasi dalam penelitian ini adalah pasien demam tifoid. Sampel pada penelitian ini adalah darah vena pasien rawat inap dan rawat jalan yang terkena demam tifoid dengan hasil pemeriksaan widal titer 1/160-1/320. Sampel yang dibutuhkan pada penelitian ini adalah 30 pasien yang berada di RSUD. RA Basoeni, Gedeg Mojokerto.

\section{Tempat dan Waktu Penelitian}

Penelitian ini dilakukan di Laboratorium RSUD. RA Basoeni, Gedeg Mojokerto Penelitian ini dilakukan april 2021

\section{Alat dan Bahan}

Alat yang digunakan pada penelitian ini adalah Hematologi Analyzer, mikroskop, plate CRP, batang pengaduk, mikropipet, pipet tetes. Bahan yang digunakan adalah sampel darah EDTA 10\%, serum, spuid, yellow tip, antihuman CRP antibody, control positif, control negatif.

\section{E. Tahap Penelitian}

1. Tahap Persiapan

Persiapan yaitu tahap dimana peneliti melakukan persiapan alat, bahan dan pengambilan darah vena. pengambilan darah vena yang pertama yaitu tentukan lokasi penusukan. Pasang tourniquet pada lengan atas. Fiksasi vena dengan kapas alcohol 70\% Lakukan penusukan arah jarum sejajar arah vena, lubang jarum menghadap ke atas. Bila arah tepat akan tampak darah memasuki pangkal jarum. Hisap pelan-pelan yang diperlukan. Lepas tourniquet, tekan tempat penusukan dengan kapas steril, cabut jarum pelan-pelan. Masukkan darah ke botol EDTA dengan tabung antikoagulan.

\section{Prosedur Pemeriksaan Widal}

Pengujian ini menggunakan metode slide atau Slide Aglutination. Pipet serum masing-masing, 20 $\mu 1,10 \mu 1$, dan $5 \mu$ kedalam tiap lingkaran yang telah ditetesi serum, maka pengencerannya adalah 1:80, 1:160, 1:320. Campur reagen widal dan serum hingga homogen dengan menggunakan batang pengaduk yang tersedia didalam kotak reagen. Kemudian baca hasil dalam waktu $>1$ menit. Bila terjadi aglutinasi, dikatakan reaksi widal positif dan jika tidak terjadi aglutinasi dikatakan negatif [8].

\section{Prosedur Pemeriksaan Leukosit}

Tahap pengujian ini menggunakan alat hematologi analyzer. Nama Alat Nihon Kohden tipe Alat MEK 6410K. Homogenkan tabung EDTA yang berisi darah. Tekan OK pada alat lalu masukkan sampel pada jarum hingga hampir menyentuh dasar botol sampel. Kemudian tekan count switch dan biarkan hingga jarum naik ke atas. Lalu Tarik tabung EDTA tersebut dan tunggu \pm 1 menit hingga hasil sampel keluar pada layar. Isi identitas pada layar yang sesuai dengan identitas pada blanko permintaan. Tekan save, kemudian tekan preview dan print.

\section{Prosedur Pemeriksaan CRP (C-Reactive Protein)}

\section{$>$ Pemeriksaan Kualitatif}

Pada pemeriksaan kadar CRP menggunakan metode kualitatif, jika hasil dari kualitatif menunjukkan CRP positif maka dilanjutkan metode semi kuantitatif. Dipipet ke atas lingkaran s 3 le sampel serum sebanyak 1 tetes $(50 \mu \mathrm{L})$, kontrol positif $(\mathrm{CP})$ dan kontrol negatif $(\mathrm{CN})$. Kemudian ditambahkan 1 tetes reagen lateks (antigen $\mathrm{CRP}$ ) masingmasing ke atas lingkaran tersebut. Dihomogenkan dengan cara memutar pada rotator dengan kecepatan $100 \mathrm{rpm}$ \$3 ama 2 menit. Setelah itu, hasil dibaca di bawah sinar terang. Aglutinasi yang terjadi menunjukkan CRP positif (CRP dalam spesimen $\geq 6 \mathrm{mg} / \mathrm{L}$ ).

\section{$>$ Pemeriksaan Kuantitatif}

Serum dengan metode kualitatif positif dilakukan pengenceran sampel secara seri, dengan cara: dipipet sebanyak $50 \mu \mathrm{L} \mathrm{NaCl} 0,9 \%$ ke atas 6 lingkaran slide. Setelah itu, dipipet $50 \mu \mathrm{L}$ serum ke atas lingkaran I (pengenceran 2 kali), dihomogenkan. Dipipet suspensi dari lingkaran I sebanyak $50 \mu \mathrm{L}$ ke atas lingkaran II (pengenceran 4 kali), sampai ke slide V (penger 3 ran 32 kali). Dipipet sebanyak $50 \mu \mathrm{L}$, ke lingkaran VI (untuk stok), jika masih menunjukkan hasil positif pada lingkaran V. Setelah itu, ditambahkan ke atas masing- 
masing lingkaran reagen lateks CRP sebanyak 1 tetes. Dihomogenkan dengan cara memutar pada rotator dengan kecepatan $100 \mathrm{rpm}$ selama 2 menit. Setelah itu, hasil dibaca di bawah sinar terang. Pengenceran tertinggi yang masih positif (tampak aglutinasi) dikalikan dengan $6 \mathrm{mg} / \mathrm{L}$ menunjukkan titer CRP dalam spesimen serum yang di periksa.

\section{Teknik Analisa Data}

Data yang diperoleh dalam penelitian ini dianalisis dengan menggunakan software statistic SPSS versi 16.0. Untuk menentukan normalitas suatu kelompok data adalah dengan menggunakan uji Shapiro-Wilk (untuk sampel $<50$ ). Distribusi tidak normal maka dilakukan secara statistik dengan melakukan uji statistik non parametrik Spearman.

\section{Etika Penelitian}

Peneliti telah melakukan uji kelayakan etik dan mendapatkan sertifikat ethical clearance nomor 191/HRECC.FODM/IV/2021 dari Fakultas Kedokteran Gigi Universitas Airlangga Surabaya.

\section{HASIL Dan PEMbaHaSan}

\section{A. Analisis Data}

Berdasarkan penelitian yang dilakukan 5 hadap hubungan jumlah leukosit dan kadar CRP (C-Reactive Protein) pada pasien demam tifoid, didapatkan hasil pada Tabel 4.1.

Tabel 4.1 Rerata \pm Standar Deviasi (SD) Jumlah Leukosit dan kadar CRP (C-Reactive Protein) pada pasien demam tifoid

\begin{tabular}{lc}
\hline \multicolumn{1}{c}{ Variabel } & Rata-rata \pm SD \\
\hline Jumlah leukosit $\left(10^{3} / \mu \mathrm{L}\right)$ & $12.997 \pm 7,276$ \\
Kadar CRP $(\mathrm{mg} / \mathrm{l})$ & $24,4 \pm 35,16$ \\
\hline
\end{tabular}

Berdasarkan Tabel 4.1. menunjukkan bahwa rata-rata jumlah leukosit dari 30 pasien widal positif yang diteliti adalah $12.99710^{3} / \mu \mathrm{L}$ jumlah leukosit terendah adalah $3.40010^{3} / \mathrm{L}$ dan jumlah leukosit tertinggi adalah 33.400 $10^{3} / \mu \mathrm{L}$ sedangkan rata-rata kadar CRP sebesar $24,4 \mathrm{mg} / \mathrm{l}$ kadar CRP terendah adalah 0 dan kadar CRP tertinggi adalah 96.

Uji normalitas menggunakan metode Shapiro-Wilk yang dilakukan pada jumlah leukosit dan kadar CRP pasien demam tifoid menunjukkan bahwa data tidak terdistribusi normal dengan nilai signifikansi berturut-turut $\mathrm{p}=0,000$ dan 0,043 .

Tabel 4.2 Uji normalitas jumlah leukosit dan kadar CRP pasien demam tifoid

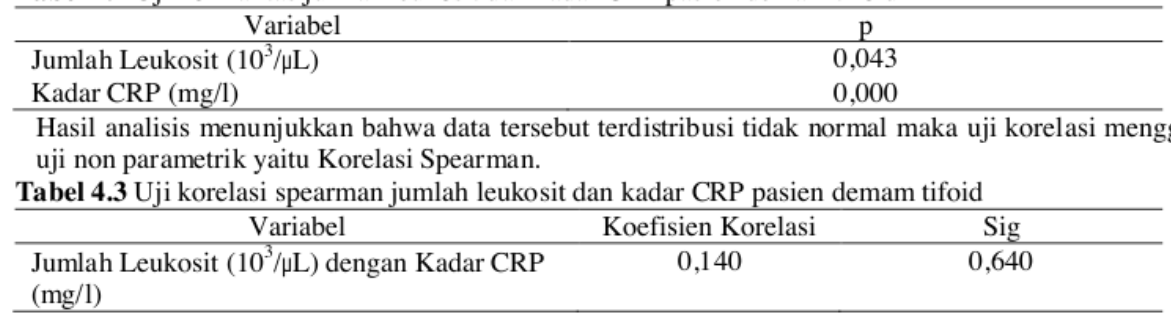

Berdasarkan hasil korelasi Spearman didapatkan koefesien korelasi atau $r=0,140$ yang menunjukkan adanya hubungan yang sangat lemah antara jumlah leukosit dengan kadar CRP $(C$-Reactive Protein $)$, sedangkan nilai $\mathrm{p}=$ 0,640 yang menunjukkan tidak terdapat hubungan signifikan antara jumlah leukosit dengan kadar CRP.

\section{B. Pembahasan}

Penyakit Typhoid Fever (TF) atau masyarakat awam mengenalnya dengan tifus ialah demam yang disebabkan oleh infeksi bakteri Salmonella typhi dan menyebar ke seluruh tubuh. Salmonella typhi (S. typhi) merupakan kuman pathogen penyebab demam tifoid, yaitu penyakit infeksi sistemik yang disertai demam jangka panjang, adanya bacteremia disertai inflamasi yang dapat merusak usus dan organ-organ hati. Setelah penderita terinfeksi bakteri tersebut, gejala penyakitnya akan berlangsung selama satu hingga dua minggu. Gejala umum yang terjadi pada penyakit tifoid adalah demam naik secara bertangga pada minggu pertama lalu demam menetap 
(kontinyu) atau remiten pada minggu kedua. Demam terutama sore/malam hari, sakit kepala, nyeri otot, anoreksia, mual, muntah, obstipasi atau diare [9].

Berdasarkan penelitian yang dilakukan di Laboratorium RSUD diperoleh hasil yaitu: rata-rata jumlah leukosit 12,997 yang artinya normal pada orang sehat, sedangkan rata-rata nilai CRP sebesar 24,4 yang artinya lebih dari nilai rujukan CRP. Perhitungan menggunakan korelasi spearman didapatkan nilai koefisien korelasi atau $r$ sebesar 0,140 yaitu adanya hubungan yang sangat lemah antara jumlah leukosit dengan kadar CRP, sedangkan nilai $\mathrm{p}=$ 0,65 yang menunjukkan tidak ada hubungan yang signifikan antara jumlah leukosit dengan kadar CRP.

Hasil penelitian ini sesuai dengan penelitian yang dilakukan oleh Cita pada tahun 2011 yaitu pada gambaran abnormal pemeriksaan hematologi yang sering ditemukan pada penderita demam tifoid yaitu leukopeni, leukositosis, atau leukosit normal, aneosinofilia, limfopenia, limfositosis, monositosis, peningkatan laju endap darah, anemia ringan,dan trombositopenia. Selain itu, penelitian ini juga sesuai dengan penelitian yang dilakukan oleh Yolanda pada tahun 2017 [10] didapatkan hasil CRP rata-rata 18,40 mg/L.

Penelitian terdahulu yang dilakukan Syamsul Arifin [11]jumlah leukosit pada penderita demam tifoid didapatkan hasil 20 penderita (65\%) demam tifoid dengan kadar leukosit normal dan 11 penderita (35\%) demam tifoid dengan kadar leukosit abnormal. Dari data tersebut diketahui bahwa penderita demam tifoid dengan kadar leukosit normal lebih banyak daripada penderita demam tifoid dengan kadar leukosit abnormal. Abro et al (2009) [12] telah melaporkan bahwa pada penderita demam tifoid hanya 14,6\% penderita saja yang kadar leukositnya abnormal. Sedangkan penelitian pada penelitian Choo et al tahun 2001 [13] menyatakan kadar CRP pada anak dengan kultur S.typi positif, uji Widal dan Typhidot positif sebesar $43 \mathrm{mg} / \mathrm{L}$. Penelitian Adeputri tahun 2016 menyatakan kadar CRP pada pasien demam tifoid sebesar $53 \mathrm{mg} / \mathrm{L}$. Hal ini dapat terjadi mungkin karena adanya perbedaan metode pemeriksaan kadar CRP dan subjek penelitian juga berbeda. Namun demikian, tetap saja terjadi peningkatan kadar CRP pada pasien demam tifoid yang melebihi nilai rujukan pada orang sehat [13;14]

Selama terjadi infeksi, produk seperti lipopolisakarida (LSP) mengaktifkan magrofag dan sel lain untuk melepaskan berbagaisitokin seperti Interleukin 1, Interleukin 6, Interleukin 8 dan TNF sebagai respon imun nonspesifik terhadap antigen bakteri. Sitokin-sitokin ini merangsang hati untuk mensintesis dan melepas sejumlah protein plasma yang disebut protein fase akut, seperti C-Reactive Protein, Mannan Binding Lectin (MLB), asam glikoprotein A1, komponen amiloid P serum seruloplastin, dan fibrinogen (Longo dan Fauci, 2013; [15]. Penelitian yang dilakukan Amal et al 2012 tentang efek demam tifoid terhadap sitokin (Interleukin 6 dan 8) dan $C$ Reactive Protein menunjukkan bahwa terjadi peningkatan signifikan dari rata-rata Il-6, Il-8 dan CRP yang berturutturut sebesar $153 \mathrm{pg} / \mathrm{ml}, 131 \mathrm{pg} / \mathrm{ml}$ dan $37,2 \mathrm{mg} / \mathrm{L}$ [16].

\section{KESIMPULAN}

Kesimpulan dari penelitian ini adalah tidak ada hubungan yang signifikan antara jumlah leukosit dengan kadar $\operatorname{CRP}(p=0,460)$.

\section{UCAPAN TERIMA KASIH}

Peneliti mengucapkan terima kasih kepada Laboratorium RSUD R.A Basoeni Mojokerto serta pihak-pihak yang telah membantu dalam penelitian ini.

\section{REFERENSI}

[1] Kasper, D.L., Fauci, A.S., Longo, D.L., Braunwald, E., Hauser, S.L., and Jameson, J.L. (2005). Harrison's principlesof Internal Medicine 16th edition. New York: McGraw-Hill. Retrieved from https://accessmedicine.mhmedical.com/book.aspx?bookID=2129

[2] Departemen Kesehatan Jawa Timur. (273). Profil Kesehatan Propinsi Jawa Timur.

[3] Widodo, D. (2006). Demam Tifoid : Buku Ajar Ilmu Penyakit Dalam Jilid III (IV). Jakarta: Pusat Penerbit 6 epartemen Ilmu Penyakit Dalam Fakultas Kedokteran Universitas Indonesia.

[4] World Health Organization. (2011). Typhoid and other invasive salmonellosis. WHO: Geneva

[5] Rosinta, L., Suryani yani dewi., \& Nurhayati, E. (2014). Hubungan durasi deman dengan kadar leukosit pada penderita demam tifoid anak usia 5-10 tahun yang dirawat inap di Rumah sakit Al-ihsan perioe januaridesember tahun 2014. Karya ilmiah, Universitas Islam Bandung, 43-48. Retrieved from http://karyailmiah.unisba.ac.id/index.php/dokter/article/download/1221/pdf

[6] Irawati., Melinda, H., \& Idjradinata, P.S. (2010). Kesesuaian nilai C-reaktif protein dan procalcitonin dalam diagnosis pneumonia berat pada anak. Jurnal saripediatri, 12(2),78-81. Retrieved from https://saripediatri.org/index.php/saripediatri/article/view/527 
[7] Subanda, I.B., Purniti, N.P.S. (2010). Faktor-faktor yang Berhubungan dengan Pneumonia bakteri pada anak. . Sari Pediatri. Universitas Udayana. 12 (3), 184- 9. DOI: http://dx.doi.org/10.14238/sp12.3.2010.184-9. Retreived from https://saripediatri.org/index.php/sari-pediatri/article/view/512

[8] Handojo I., Edijanto SP., Probohoesodo MY \& Mahartini NN. (2004). Comparison of the diagnostic value of local Widal slide test with imported Widal slide test. The Southeast Asian Journal of Tropical Medicine and Public Health. 35 (2):366- 370. Retrieved from https://www.semanticscholar.org/paper/Comparison-ofthediagnostic-value-of-local-Widal-HandojoEdijanto/3a6c2e9185172bae8dc00d35d9b61392119c3c47.

[9] Dimitrov, T., Eded, E., Ossama, Albaksami., Shehab Al-Shehab., Abdul Kilani., Medhat, Shehab and Aref, AlNakkas. (2007). Clinical and microbiological investigation of typhoid rever in an infectious disease hospital in Kuwait. Journal of Medical Microbiology. 56 (2),538-544. DOI 10.1099/jmm.0.46814-0

[10] Sari, C.Y., Santosa, B., \& Prastiyanto, M, E. (2017). Hubungan Kadar C-Reactive Protein Dengan Laju Endap Darah Pada Pasien Widal Positif. Skripsi. Universitas Muhammadiyah Semarang. Retrieved from https://repository.unimus.ac.id/1207

[11] Arifin, S., Hartoyo, E., \& Srihandayani, D. (2009). Hubungan Tingkat Demam dengan Hasil Pemeriksaan Hematologi pada Penderita Demam Tifoid. Skripsi Universitas Lambung Mangkurat Kalimantan. Retrieved from http://repository.unimus.ac.id/id/eprint/1253

[12] Abro, A. H., Abdou, A. M., Gangwani, J. L., Ustadi, A. M., Younis, N. J., \& Hussain, H. S. (2009). Hematological and Biochemical Changes In Typhoid Fever. Pakistan Journal Of Medical Science, 25, 166171.

[13] Choo, K.E., David, T.M.E., Henry, R.L., Chan L.P., (2001). 'Serum C-Reactive Protein Concentrations in Malays 11. Children with Enteric Fever'. Journal of Tropical Pediatrics, vol. 47, pp. 211-214. .

[14] Idhyu, A.T. (2014). Perbedaan Kadar C-Reactive Protein pada Demam Akut karena Infeksi Dengue dan Demam Tifoid. Jurnal Penyakit Dalam, 3 (3), 138-141. Retrieved from http://jurnalpenyakitdalam.ui.ac.id/3 dex.php/jpdi/article/view/24/21.

[15] Bratawidjaja, K dan Rengganis, I. (2010). Imunologi Dasar. Jakarta: Balai Penerbit Fakultas Kedokteran Universitas Indonesia.

[16] Agustin \& Melati. (2016). Gambaran C-reaktif Protein Pada Obesitas. Karya Tulis Ilmiah. Politeknik Kesehatan $\quad$ Bandung. $\quad 9-27 . \quad$ Retrieved from http://repository.poltekkesbdg.info/files/original/22bfe67a79c87259c1b5b7977 528fcf5.pdf 
ARTIKEL ALDA MEGAWATI.pdf

ORIGINALITY REPORT

$15 \%$

SIMILARITY INDEX
$15 \%$

INTERNET SOURCES
$5 \%$

PUBLICATIONS
$4 \%$

STUDENT PAPERS

PRIMARY SOURCES

1 journal.thamrin.ac.id

Internet Source

2 saripediatri.idai.or.id

3 journal.poltekkes-mks.ac.id

4 repository.unissula.ac.id

5 idoc.pub

Internet Source

6 conference.upnvj.ac.id 